\title{
The objectives and legal instruments of Municipal Waste Management in the Slovak Republic
}

\section{Introduction}

In particular, two types of data are important for assessing the state of waste management in each Member State of the European Union - first, the amount of the waste generated per capita annually and waste recovery rate, second, the rate of waste disposal in accordance with the waste hierarchy.

The latest available statistics on the amount of waste generated per capita are for 2018. While the European Union average is $492 \mathrm{~kg}$ of municipal waste produced per capita for 2018, the Slovak Republic's waste production is slightly less than that, with an average of $414 \mathrm{~kg}$ of municipal waste produced per capita for 2018. ${ }^{1}$ On the other hand, Denmark with $766 \mathrm{~kg}$ of municipal waste produced per capita annually is at the bottom of the European Union ranking. The Czech Republic with $351 \mathrm{~kg}$ and Poland with $329 \mathrm{~kg}$ of municipal waste produced per capita on the average annually for the same period are in better position than Slovak Republic.

Another important data for the evaluation of the state of municipal waste management is the rate of recovery of municipal waste, alternatively - the municipal waste recycling rate. Within this scope, the Slovak Republic performs considerably worse, both regarding the waste management objectives and in comparison with the European Union average, or in comparison with remain-

${ }^{1}$ See e.g.https://ec.europa.eu/eurostat/statistics-explained/index.php/Municipal_waste_statis tics\#Municipal_waste_generation [accessed 31.03.2020]. 
ing Member States. While the average recycling rate of municipal waste in the European Union was $47.0 \%$ in 2018 , the Slovak Republic recycled only $36.3 \%$ of municipal waste in 2018. The situation within this scope in the Czech Republic/Czechia (34.5\%) and Poland (34.3\%) were similar. Germany achieved the highest municipal waste recycling rate in 2018 , up to $67.3 \% .^{2}$ Directly related to the rate of the municipal waste recovery is the high rate of waste disposal, especially in the form of landfill, which was in the Slovak Republic in 2018 amounted to $55.0 \%$. Despite the high rate of landfill, we can speak of a reduction in the landfill rate of municipal waste compared to previous years. ${ }^{3}$

From the foregoing data of selected indicators of the average recycling rate of municipal waste, it can be deduced that the system of municipal waste management in the Slovak Republic is obviously flawed, in as much as municipal waste management lacks long-term management in accordance with the waste hierarchy. The said deficiency may result either from insufficient legislation pertaining to this area or failure in terms of its enforcement.

\section{Legal Framework for Municipal Waste Management}

In the context of relatively extensive waste management legislation, I will focus in particular on the waste hierarchy and waste management objectives with regard to municipal waste.

In particular, the basic legal framework for waste management is Directive on waste. ${ }^{4}$ The waste management system in accordance with the waste hierarchy set out in the said directive is then complemented by other directives governing the management of selected categories of waste, in particular Directive on waste electrical and electronic equipment (WEEE), Directive on batteries and accumulators and waste batteries and accumulators and Directive on end-of life vehicles. ${ }^{5}$ The fundamental basis for the waste management in general and

${ }^{2}$ See e.g. https://ec.europa.eu/eurostat/databrowser/view/sdg_11_60/default/table?lang=en or https://www.enviroportal.sk/spravy/detail/10261? p=9341 [accessed 31.03.2020].

${ }^{3}$ See e.g. https://euractiv.sk/section/obehova-ekonomika/news/slovensko-ma-lepsie-odpado ve-statistiky-skladkuje-pritom-coraz-viac/ [accessed 31.03.2020].

${ }^{4}$ Directive 2008/98/EC of the European Parliament and of the Council of 19 November 2008 on waste and repealing certain Directives, available e.g. at https://eur-lex.europa.eu/le gal-content/EN/TXT/?qid=1586513366116\&uri=CELEX:02008L0098-20180705 [accessed 31.03. 2020].

${ }_{5}^{5}$ Directive 2012/19/EU of the European Parliament and of the Council of 4 July 2012 on waste electrical and electronic equipment (WEEE), Directive 2006/66/EC of the European Parliament and of the Council of 6 September 2006 on batteries and accumulators and waste batteries and accumulators and repealing Directive 91/157/EEC, Directive 2000/53/EC of the European 
municipal waste management in particular is, in my view, the waste hierarchy, which is based not only on other European Union legislation but also on Member States' respective legislation, including the strategic documents adopted within this area to achieve the objectives set and regulating further details, in particular in the form of specifying measures for individual areas of waste management.

According to the Waste Framework Directive, the waste hierarchy should be applied as a priority to waste management in waste prevention and waste legislation and policies. When applying the waste hierarchy, Member States shall take measures to encourage the options that deliver the best overall environmental outcome, while at the same time Member States shall make use of economic instruments and other measures to provide incentives for the application of the waste hierarchy. ${ }^{6}$

In the Slovak Republic, the issue of waste management as well as the waste hierarchy is regulated by the Act on Waste, ${ }^{7}$ which identifies this hierarchy as a binding order of waste management priorities, from which it is possible to deviate only in certain cases and if provided for by the Act. Subsequent waste management obligations are then imposed on individual entities in accordance with the waste hierarchy.

In addition to the Act on Waste, municipal waste management in the conditions of the Slovak Republic is also influenced by secondary legislation (sub laws/acts), which are generally binding regulations of municipalities as bodies of territorial self-government, which regulate the details of municipal waste management in municipalities. In these generally binding regulations, municipalities specify details on the method of collection and transport of municipal waste, the method of separate collection of individual components of municipal waste, the method of management of small construction waste and household electrical waste, as well as places for the disposal of such waste. ${ }^{8}$

Another important policy component is setting waste management objectives. The Waste Framework Directive (or WFD) sets the following objectives for Member States in the field of municipal waste:

a) by 2020 , the preparation for re-use and the recycling of waste from households shall be increased to a minimum of overall $50 \%$ by weight;

b) by 2025 , the preparing for re-use and the recycling of municipal waste shall be increased to a minimum of $55 \%$ by weight;

c) by 2030 , the preparing for re-use and the recycling of municipal waste shall be increased to a minimum of $60 \%$ by weight;

Parliament and of the Council of 18 September 2000 on end-of life vehicles, available e.g. at https://eur-lex.europa.eu.

${ }^{6}$ Directive on waste, Article 4.

7 Act No. 79/2015 Coll. on Waste and on amendments to certain acts, as amended, available at https://www.slov-lex.sk/pravne-predpisy/SK/ZZ/2015/79/20200101 [accessed 31.03.2020].

${ }^{8}$ See B. Cepek et al.: Environmentálne právo. Všeobecná a osobitná čast'. Plzeň 2015, p. 364. 
d) by 2035, the preparing for re-use and the recycling of municipal waste shall be increased to a minimum of $65 \%$ by weight.

These objectives are also assumed by the Slovak Act on Waste, which transposes the objectives of the Directive into national legislation. It also should be noted that the minimum recovery targets are set by WEEE, Directive on batteries and accumulators and waste batteries and accumulators (minimum collection limits under Article 10 of the Directive) as well as by Directive on end-of life vehicles (recovery and recovery targets under Article 7 of the Directive). Waste management targets and binding limits for these categories of waste (electrical waste, used batteries and accumulators, old vehicles) are also regulated by the Act on Waste in its Annex No. 3. The absence of specific measures could be assessed as a practical lack of regulation, especially at the legal level, but these aspects are also covered by the legislation.

The specification of measures to achieve the objectives of waste management is not contained directly in the Act on Waste, but in the waste management programmes foreseen by the law. The Waste Management Programme is a policy document that is drawn up in accordance with the waste hierarchy and objectives. It includes an analysis of the current state of waste management and describes measures to be taken to improve environmentally sound recovery and disposal. It is developed at three levels - for the entire territory of the Slovak Republic, for the territory of the region and for the territory of some municipalities.?

On the basis of the above-mentioned legal framework, one may conclude in part that the legislation on municipal waste management could be seen as sufficient, since it regulates the individual obligations of Member States, establishes the waste hierarchy, sets recovery targets or recycling targets for municipal waste, and based on the foregoing particular programme documents containing concrete measures to achieve the objectives of waste management are adopted.

\section{The Execution of Selected Subjects' Responsibilities in Municipal Waste Management}

Compliance with the waste hierarchy, the achievement of waste management objectives and the implementation of measures to meet the objectives are the responsibility of several subjects involved in the management of municipal waste.

The most important subjects in this area include: households, municipalities, producers, entities involved in waste recovery that process separate categories of waste.

${ }^{9}$ See P. TAKáč: Zákon o odpadoch. Praktický komentár. Bratislava 2016, pp. 27 ff. 
Households buy products from producers and produce municipal waste after they have used them. Their most important task in the field of municipal waste management is to separate as much of the municipal waste as possible and then transmit it to subjects responsible for its further processing. In carrying out these tasks, they are limited not only by law, but also by setting specific measures of the system that either motivate or discourage them from separating municipal waste. The achievement of municipal waste management goals depends on household waste separation.

Municipalities are responsible for the management of mixed municipal waste, bear the additional costs and, in relation to households, they largely establish the detailed rules of municipal waste management in the municipality, as they adopt generally binding regulations on municipal waste management. Another important instrument available to municipalities is the determination of the amount of the local fee for municipal waste and small construction waste. They also determine the amount of the fee in the form of a generally binding regulation..$^{10}$ In my opinion, municipalities along with the extended producer responsibility within the framework of the legislation, have the possibility and space to set further details of municipal waste management in the municipality so as to significantly support the separation of municipal waste by households. This is possible both by setting of cost of municipal waste and, secondly, in the case of the producers, by specifying the conditions for collection, removal, and subsequent processing of separated categories of waste. It is my opinion that municipalities do not realise this potential. They rather merely copy the legal framework established by the Act on Waste into the generally binding regulation. It is questionable whether this potential is not utilised due to inexperienced employees and management of municipalities, due to their financial limitations, or other reasons.

The role of producers is also very important and irreplaceable in the municipal waste management system. Producers are obliged to take into account the environmental impact of their products such as future waste during all phases of the product life cycle. Thus, certain aspects and impacts must be taken into account at the product manufacturing stage. These include, in particular, the use of appropriate materials that both minimise environmental impact and are also suitable for the recovery process. At the same time, producers should play an important role in fulfilling the first point of the waste hierarchy, namely waste prevention. Here, however, one may notice a major problem and contradiction between the objectives of waste management and those of producers as entrepreneurs. While the aim of the waste hierarchy is to produce as little waste as possible, producers as entrepreneurs aim to achieve the highest pos-

${ }^{10}$ This procedure is in accordance with $\S 83$ of Act No. 582/2004 Coll. on local taxes and local fees for municipal waste and small construction waste, as amended. 
sible profit, which otherwise means the highest possible production capacity. Therefore, the role of legislation and the resulting legal instruments and policy measures is important to force or motivate producers to take waste prevention into account. Another very important task for producers is the management of selected categories of waste (e.g. WEEE, used batteries and accumulators, packaging). Producers are responsible for collecting, transporting, and transmitting these categories of waste to the waste-processing entities, and at the same time, incur the costs involved.

Consequently, the entities that process selected categories of waste have the task of recovering waste as much as possible, thereby reducing waste. Another positive effect of their activities is the conservation of natural resources, so as raw materials derived from waste and not natural resources are used to some extent to produce other products.

At this point, the question arises as to which of those entities is the most important one in the course of achieving the waste management objectives. In my opinion, each of them has an important role, which is essential at the appropriate stage of municipal waste management. If any of these subjects fails, the whole system becomes ineffective or inoperative. Households play an irreplaceable role in increasing the share of separated waste from the total amount of municipal waste, municipalities and producers create conditions for the abovementioned separation, collection, and transport of individual components of municipal waste and processors contribute to the reuse of waste as raw material to be used production.

A partial conclusion of this section could be that the roles and responsibilities of the different entities in the field of municipal waste management are clear, but the potential that these they can tap into in order to achieve the waste management objectives remains questionable.

\section{Methods and Instruments to Achieve Waste Management Objectives}

The waste management objectives can be achieved using a number of appropriate methods and instruments.

One must consider the general methods of administrative law, in particular the method of coercion and the method of persuasion, to be appropriate methods applicable within this area.

The method of coercion is manifested in particular by establishing obligations for individual subjects carrying out tasks in the field of municipal waste management. These entities were discussed in the previous section. Furthermore, the application of this method requires the competent public authorities 
to address non-compliance and act to bring about the desired situation. Using coercive methods, we then distinguish between direct coercion and indirect coercion. ${ }^{11}$

The persuasion method usually requires systematic and long-term action, and the result may be uncertain. Here again, we distinguish between the method of direct persuasion and the method of indirect persuasion. ${ }^{12}$ Despite the uncertain outcome and the need for long-term action, however, in some areas, the use of persuasion methods may be more appropriate than coercive methods, respectively a combination of both may be used. In achieving the waste management objectives, I would claim that the combination of both methods to be the most appropriate.

In particular, waste management programmes can be used to specify measures concerning the management of municipal waste. In order to present some examples of those measures, I have selected the current programme covering the entire territory of the Slovak Republic, that is, the Waste Management Programme of the Slovak Republic for 2016-2020. ${ }^{13}$ This programme document contains both an assessment of the current state of waste management, waste management objectives for the relevant period ${ }^{14}$ (the main objective and the particular objectives for each category of waste), as well as concrete measures to achieve the main objective and sub-objectives.

The main objective of the waste management to be met by the year 2020, according to the document, is to minimise the negative effects of waste producing and waste management on human health and the environment, while achieving more substantial enforcement and adherence to a binding waste hierarchy, in particular to increase waste recycling, mainly municipal waste. The fundamental objective is the substantial decrease of waste from its disposal by landfill. The partial objective for municipal waste, in turn, is to increase the preparation for re-use and recycling of household waste (such as paper, metal, plastic, and glass) by at least $50 \%$ by weight by 2020 . At the time of its adoption in 2016, the objectives stipulated by the programme were even more ambitious than those stated in the Waste Framework Directive, as the projected 50\% municipal waste collection rate was set for 2019 and the 2020 municipal waste collection rate amounted to $60 \%$ of the overall weight. In particular, the following measures have been agreed to achieve the objectives for municipal waste:

- implementing the principle of extended producer responsibility in the system of separate collection of municipal wastes for the components of municipal wastes to which the principle of extended producer responsibility is applied;

${ }^{11}$ See e.g. M. VRabKo et al.: Správne právo hmotné. V̌̌eobecná čast'. Bratislava 2012, p. 188.

12 Ibidem.

${ }_{13}$ Available e.g. at https://www.minzp.sk/files/sekcia-enviromentalneho-hodnotenia-riadenia /odpady-a-obaly/registre-a-zoznamy/poh-sr-2016-2020_vestnik.pdf [accessed 31.03.2020].

${ }^{14}$ In this case, until 2020. 
- assessing the modification possibility of the amount and mechanism of redistribution of the landfill fees, while one of the principles of the new economic instrument must be that the amount of fees for landfill must be based on the rate of sorting of municipal waste;

- based on the continuous increase in efficiency of collection of segregated municipal waste in connection with the objectives of municipal waste recycling, to assess the possibility of introduction a new system of collection of single-use beverage packaging.

In practice, the first enumerated measure was implemented relatively quickly after the adoption of the waste management programme, but authorities postponed the implementation of the remaining ones. The result of not taking further measures, or their under-implementation, had a negative impact on the landfill rate of municipal waste (high landfill rate) and the recycling rate of municipal waste (low recycling rate). Despite the downward trend, municipal waste landfill rates are insufficient and fall short of the objectives set. The landfill rate of municipal waste was as follows - in 2015 it was at the level of $70 \%$ of the weight of waste, in $2016-66 \%$, in 2017 it was $61 \%$, and in 2018 it was $55 \%$ of the weight of waste..$^{15}$ The recycling rate is on an upward trend, but it is very likely that the Slovak Republic will not meet its 2020 target. The evolution of the recycling rate is as follows - in 2015 it was only $14.9 \%$, in $2016-23.0 \%$, in 2017 it increased to $29.8 \%$, and in 2018 it reached $36.6 \% .^{16}$

Based on this underperformance, the European Commission issued The Early Warning Report for Slovakia in September 2018 as an accompanying document to the Commission Report to the European Parliament, the Council and relevant committees on the implementation of EU legislation on waste, including the early warning report for Member States at risk of missing the 2020 preparation for re-use/recycling target on municipal waste. ${ }^{17}$ The Commission stipulates in the document that the attaining the 2020 target of preparing for reuse/recycling of $50 \%$ of municipal waste is at risk. It considers in particular the main reasons for this situation:

- the separate collection of recyclables, including bio-waste, is not yet being carried out effectively;

- economic incentives for households to separate waste are lacking;

- the extended producer responsibility schemes in Slovakia do not fully cover the costs of separate collection;

${ }^{15}$ See e.g. https://euractiv.sk/section/obehova-ekonomika/news/slovensko-ma-lepsie-odpado ve-statistiky-skladkuje-pritom-coraz-viac/ [accessed 31.03.2020].

${ }^{16}$ See e.g. https://ec.europa.eu/eurostat/databrowser/view/sdg_11_60/default/table?lang=en [accessed 31.03.2020].

${ }^{17}$ Document available e.g. at https://ec.europa.eu/environment/waste/pdf/early_warning_re port_SK.pdf [accessed 31.03.2020]. 
- more investment is needed in projects higher up the waste hierarchy (e.g. recycling) that go beyond treatment of residual waste.

Based on the above findings, the Commission recommended in the form of 18 proposals that the Slovak Republic should take measures to support the efforts of the Slovak Republic to improve its waste management performance. The recommended measures included, for example, specifying economic incentives for municipalities (e.g. revision of landfill fee), extended producer responsibility programmes (revision of the financing of separate collection costs), municipality involvement, absorption of European Union funds (incentives for households high recycling rates and corresponding increase in fees), bio-waste management (e.g. abolition of all exceptions to the law) and technical support provided to municipalities.

Subsequently (probably also on the basis of the above-mentioned Commission recommendations) two laws were adopted. The first is Act No. 329/2018 Coll. on Waste Deposit Fees and on the amendment of Act no. 587/2004 Coll. on the Environmental Fund and on amendments to certain acts, as amended, ${ }^{18}$ which regulates the payment of charges for the dumping of waste in a landfill. However, it is interesting to calculate the amount of the landfill fee, which depends on the level of sorting of municipal waste - the higher the level of sorting of municipal waste, the lower the price for depositing 1 tonne of waste in a landfill. ${ }^{19}$ Another adopted law, which should help to improve the unflattering situation of the conditions of municipal waste management, is Act No. 302/2019 Coll. on pre-paid of disposable packaging for beverages and on amendments and supplements to certain acts, as amended..$^{20}$ This legislation introduces a system for pre-paid disposable beverage containers, both plastic beverage containers (PET bottles) and metal beverage containers (cans). We are not yet able to assess in perspective the impact of this legislation on the achievement of the municipal waste management objectives, as Act No. 329/2018 Coll. came into effect only on 1 January 2019 and Act no. 302/2019 shall only enter into force on 1 January 2022.

However, in our opinion, approval of the measures mentioned can be assessed positively because, in terms of the measures implemented under them, it is expected to have a positive impact on reducing the amount of municipal waste collected to landfill as well as increasing the recycling rate of (at least) selected categories of municipal waste.

${ }_{18}$ Available at https://www.slov-lex.sk/pravne-predpisy/SK/ZZ/2018/329/20190426 [accessed 31.03.2020].

${ }_{19}$ For more details on this law, see e.g. Čerňanová, L., Dufala, M., Michalovič, M.: Current Trends in the Slovak Legal System in the Area of Waste Management. In: Acta Universitatis Carolinae. - Roč. 65, č. 3 (2019), s. 89. Dostupné na https://www.prf.cuni.cz/sites/default/files /soubory/2019-12/archiv_Iuridica_3_2019.pdf [accessed 31.03.2020].

${ }^{20}$ Available at https://www.slov-lex.sk/pravne-predpisy/SK/ZZ/2019/302/20200101 [accessed 31.03.2020]. 
The partial conclusion of this section should be an evaluation of the measures taken to achieve the waste management objectives. Despite the fact that several measures in this area are approved, the objectives have not been achieved. This may be because the measures are insufficient or not formulated in sufficient detail to allow individual subjects in the field to contribute to the objectives set, or they are not properly implemented.

\section{Conclusions}

Although the trends in data of the two monitored areas have been developing advantageously - municipal waste recycling rates are increasing and municipal waste landfilling rates are decreasing - the Slovak Republic still failsto meet its waste management objectives. It is very likely that we will not meet the target of at least $50 \%$ municipal waste recycling by the end of 2020. In this article, I attempted to analyse the reasons why the Slovak Republic is having difficulty in achieving this objective.

First, I dealt with the analysis of legislation within this area, at European Union level, then at national level in the form of particular laws, as well as at the level of municipalities that adopt generally binding regulations on waste. While I consider the first two analysed levels of regulation to be sufficient, although there are some doubts regarding the content of generally binding regulations of the municipality. I am of the opinion that municipalities in this legislation do not motivate citizens as members of households to a higher rate of segregation of municipal waste and almost in no way regulate the possibilities of waste prevention in households. ${ }^{21}$

Then, I dealt with the tasks of individual entities carrying out activities in the field of municipal waste management. Here I am of the opinion that the roles and responsibilities of individual entities are relatively clear, but the potential that these subjects can still tap into in order to achieve the waste management objectives remains questionable. In particular, we mean municipalities and producers under the extended producer responsibility, who could be more active and motivate households in relation to waste prevention and to a higher rate of household waste segregation. This need is also regulated by the Waste Management Programme of the Slovak Republic for 2016-2020, according to

${ }^{21}$ See e.g. M. Dufala, J. Šmelková: Dobré nariadenie o odpade. In: Dobré všeobecne záväzné nariadenie. Bratislava 2018, pp. 75-80 [online], available at https://www.flaw.uniba. sk/fileadmin/praf/Aktuality/2019/2019-01-30_Zbornik_dobre_VZN_KSEP.pdf [accessed 31.03. 2020]. 
which a fundamental increase in the level of separate collection of recyclable components of municipal waste is essential for meeting the $50 \%$ recycling target for municipal waste. ${ }^{22}$

Subsequently, I analysed the use of methods and, in particular, the implementation of measures taken in the field of municipal waste management. In relation to measures in the field of municipal waste management, we believe that the measures taken are not adequate, as confirmed by the Early Warning Report for Slovakia issued by the European Commission, which recommended that further measures be taken. Furthermore, I believe that some measures are not formulated in sufficient detail to allow individual actors in this field to contribute to the objectives set. The third drawback of the measures is that they are not implemented correctly, especially on the part of municipalities and producers. The reason for inadequate implementation by municipalities is insufficient expertise of municipal employees, numerous scope of tasks in different areas, and only formal declaration of implementing them. On the part of producers, the lack of implementation is, in our opinion, due to different producer targets (especially increasing product consumption and thus increasing profit) compared to waste management objectives.

Therefore, it has to be understood as crucial to motivate households to intensify the segregation and subsequent recovery of waste, especially by municipalities, which have the opportunity to use economic instruments (especially municipal waste fees) to motivate their inhabitants. The sooner the household understand that the higher rate of municipal waste segregation lowers the cost of municipal waste management, the sooner it will be feasible to achieve the waste management targets.

\section{Literature}

CEPeK, B. et al.: Environmentálne právo. V̌̌eobecná a osobitná čast'. Plzeň 2015.

Čerñanová, L., Dufala, M., Michalovič, M.: Current Trends in the Slovak Legal System in the Area of Waste Management. "Acta Universitatis Carolinae" 2019, vol. 3, pp. 85-92.

Dufala, M., Šmelková, J.: Dobré nariadenie o odpade. In: Dobré všeobecne záväzné nariadenie. Bratislava 2018.

TAKÁČ, P.: Zákon o odpadoch. Praktický komentár. Bratislava 2016.

Vrabko, M. et al.: Správne právo hmotné. V̌̌eobecná čast'. Bratislava 2012.

The Waste Management Programme of the Slovak Republic for 2016-2020 [online], https://www .minzp.sk/files/sekcia-enviromentalneho-hodnotenia-riadenia/odpady-a-obaly/registre-a-zo znamy/poh-sr-2016-2020_vestnik.pdf [accessed 31.03.2020].

22 The Waste Management Programme of the Slovak Republic for 2016-2020, p. 103. 
Martin Dufala

\title{
Cele oraz instrumenty gospodarowania odpadami komunalnymi w Republice Słowackiej
}

\begin{abstract}
Streszczenie
Artykuł dotyczy analizy gospodarki odpadami komunalnymi w Republice Słowackiej. Autor ocenia stan realizacji celów gospodarowania odpadami zgodnie z hierarchią postępowania z odpadami, zajmuje się rolą podmiotów zaangażowanych w gospodarkę odpadami komunalnymi oraz analizuje możliwe metody i instrumenty, które mogą być wykorzystane do osiągnięcia wyznaczonych celów.
\end{abstract}

Słowa kluczowe: Odpady komunalne, hierarchia postępowania z odpadami, cele gospodarowania odpadami

Марчин Дуфала

\section{Цели и инструменты управления бытовыми отходами в Словацкой Республике}

\author{
Резюме
}

Аннотация: Статья посвящена анализу управления бытовыми отходами в Словацкой Республике. Автор оценивает состояние реализации задач по управлению отходами в соответствии с иерархией отходов, рассматривает роль организаций, занимающихся управлением бытовыми отходами, и анализирует возможные методы и инструменты, которые могут использоваться для достижения поставленных целей.

Ключевые слова: Бытовые отходы, иерархия обращения с отходами, цели управления отходами

Martin Dufala

\section{Obiettivi e strumenti della gestione dei rifiuti urbani nella Repubblica Slovacca}

\section{Sommario}

Riassunto: L'articolo riguarda l'analisi della gestione dei rifiuti urbani nella Repubblica Slovacca. L'autore valuta lo stato di realizzazione degli obiettivi di gestione dei rifiuti secondo la gerarchia dei rifiuti, si occupa del ruolo dei soggetti coinvolti nella gestione dei rifiuti urbani e analizza i possibili metodi e strumenti che possono essere utilizzati per raggiungere gli obiettivi prefissati.

Parole chiave: Rifiuti urbani, gerarchia di gestione dei rifiuti, obiettivi di gestione dei rifiuti 